\title{
Role of the ubiquitin system and tumor viruses in AIDS-related
}

\section{cancer}

\author{
Julia Shackelford and Joseph S Pagano*
}

\author{
Address: Lineberger Comprehensive Cancer Center, The University of North Carolina at Chapel Hill, Chapel Hill, NC, 27599-7295, USA \\ Email: Julia Shackelford - shackelfordj@yahoo.com; Joseph S Pagano* - joseph_pagano@med.unc.edu \\ * Corresponding author
}

Published: 22 November 2007

BMC Biochemistry 2007, 8(Suppl I):S8 doi: 10.1 I86/I47I-209I-8-SI-S8

This article is available from: http://www.biomedcentral.com/|47I-209I/8/SI/S8

(C) 2007 Shackelford and Pagano; licensee BioMed Central Ltd.

This is an open access article distributed under the terms of the Creative Commons Attribution License (http://creativecommons.org/licenses/by/2.0),

which permits unrestricted use, distribution, and reproduction in any medium, provided the original work is properly cited.

\begin{abstract}
Tumor viruses are linked to approximately $20 \%$ of human malignancies worldwide. This review focuses on examples of human oncogenic viruses that manipulate the ubiquitin system in a subset of viral malignancies; those associated with AIDS. The viruses include Kaposi's sarcoma herpesvirus, Epstein-Barr virus and human papilloma virus, which are causally linked to Kaposi's sarcoma, certain B-cell lymphomas and cervical cancer, respectively. We discuss the molecular mechanisms by which these viruses subvert the ubiquitin system and potential viral targets for anticancer therapy from the perspective of this system.
\end{abstract}

Publication history: Republished from Current BioData's Targeted Proteins database (TPdb; http://www.targetedproteinsdb.com).

\section{Introduction}

Viruses are etiologically linked to approximately $20 \%$ of all human malignancies worldwide and much of what we know today about the molecular mechanisms of oncogenesis has come from the study of tumor viruses. The means by which viruses subvert the ubiquitin proteasome system (UPS) is a relatively new area of inquiry. The study of the interactions between viruses and this system not only furthers knowledge of how viruses work, but also often offers shortcuts to understanding cellular processes in general. Though the infectious nature of viruses distinguishes them from other oncogenic factors, it is the adaptation of tumor viruses, mainly DNA viruses, over millennia of co-evolution with their hosts to persistence within these hosts that make the viruses an ideal focus for study of cellular mechanisms reviewed briefly here. This perspective is valid because the immense array of normal intracellular regulatory mechanisms is for the most part intact in latently infected cells, even when they become neoplastic. This symbiosis between virus and cell is mirrored by the fact that in most infected individuals tumors do not develop, and in most instances many years pass between initial infection and appearance of a tumor. The host immune system generally keeps viral infection under control; however, conditions such as acquired immune deficiency syndrome (AIDS) elevate the risk of virus-associated malignancies dramatically [1-4].

Although human immunodeficiency virus (HIV), the cause of AIDS, itself does not have oncogenic properties, the profound immunodeficiency it causes creates a favorable environment for the development of cancer. All HIVinfected patients are at increased risk of developing several types of cancer, particularly in the later stages of AIDS. Despite highly active anti-retroviral therapy (HAART) being widely employed in developed countries, malignancy in this population is still a leading cause of morbidity and mortality $[2,5,6]$. 
Among the heterogeneous types of cancer associated with AIDS are Kaposi's sarcoma, immunoblastic B-cell lymphomas and an increased incidence of cervical and anal carcinoma $[7,8]$. Three human oncogenic viruses are involved causally: Kaposi's sarcoma herpesvirus (KSHV), Epstein-Barr virus (EBV) and human papilloma virus (HPV) $[9,10]$.

AIDS-related malignancies represent only a small portion of all virus-associated human cancers. The consistency of association between a given virus and a specific malignancy ranges from essentially $100 \%$ to as low as $15 \%$ depending on the virus, the cancer and other factors [11]. Since the UPS regulates diverse cellular functions, including transcription, stress responses, cell cycle, cellular differentiation, angiogenesis, antigen processing and DNA repair [12], it is inevitably involved in oncogenesis induced by all the human tumor viruses $[13,14]$.

Here we discuss several examples of how three tumor viruses manipulate the UPS in AIDS-associated viral malignancies, as well as provide perspectives on UPSdirected agents that might offer pathways to therapeutic intervention in these diseases.

\section{Kaposi's sarcoma and KSHV}

The search for a transmissible infectious agent as the cause of Kaposi's sarcoma led to the discovery in 1994 of KSHV, so far the newest member of the group of identified human oncogenic viruses [15-17]. Even though the incidence of Kaposi's sarcoma has fallen since the introduction of HAART, it is still the most common cancer associated with AIDS [18-21].

The ability to evade immune responses is crucial for longterm survival of viruses in the host. Oncogenic viruses make use of diverse strategies in achieving survival; one is the down-regulation of major histocompatibility complex (MHC) class I antigen presentation through the UPS $[22,23]$.

KSHV encodes several viral products with oncogenic properties, among them two proteins, K3 and K5 (also known as MIR1 and MIR2), that have ubiquitin ligase activity $[24,25]$. K3 and K5 recruit E2 enzymes with their N-terminal RING-CH domain [25]. Either direct or indirect interactions between the transmembranes of $\mathrm{K} 3$ and $\mathrm{K} 5$ and MHC class I molecules ultimately lead to the ubiquitylation of lysine residues present in the MHC class I intracytoplasmic tail $[25,26]$. Ubiquitylated MHC class I molecules are then endocytosed and degraded by the lysosome $[25,27,28]$. A recent report indicates that $\mathrm{K} 3$, but not K5, can promote down-regulation of MHC class I molecules lacking lysine residues in their intracytoplasmic domains [29]. Another study argues that lysine 63-linked ubiquitylation of MHC class I molecules is necessary for their efficient $\mathrm{K} 3$ ubiquitin ligase-mediated endolysosomal degradation [30].

Besides $\mathrm{K} 3$ and $\mathrm{K} 5$, another KSHV product, the immediate-early transcriptional transactivator RTA, is reported to encode E3 ubiquitin ligase activity [31]. RTA-dependent ubiquitylation of interferon regulatory factor 7 (IRF7), a key inducer of interferon-stimulated genes (ISGs), could target it for ubiquitin-dependent proteasomal degradation [31], thus dampening innate immune responses to the infection.

\section{B-cell lymphomas and EBV}

Several decades of intensive studies on EBV, the first human oncogenic virus discovered, have revealed its association with a variety of malignant diseases [11,32-37], including B-cell lymphomas associated with acquired and innate immunosuppressive conditions [38-42].

The EBV product EBNA1 represents an interesting example of how a virus evades immune system responses. EBNA1 is a nuclear protein that binds to EBV episomes and is required for maintenance of latency by the virus [34]. This viral protein contains repeats of Gly-Ala residues that prevent its proteasomal degradation and, additionally, sequester cleaved viral products in a cytoplasmic compartment, rendering them inaccessible for presentation by MHC class I molecules [43]. Although EBNA1 is not the only viral protein expressed during EBV latency, its resistance to UPS-dependent degradation creates a perfect camouflage to prevent recognition by the immune system [43-45].

Like other tumor viruses, EBV demonstrates its oncogenic potential by redirecting cell signaling pathways. Recent studies reveal ways in which EBV can manipulate different components of the UPS. For example, in B-cells its major oncogenic product, latent membrane protein 1 (LMP1), inhibits Siah-1 ubiquitin ligase to rescue the oncogenic factor $\beta$-catenin from proteasomal degradation $[46,47]$. In contrast, in epithelial cells LMP1 activates the same ubiquitin ligase, the targets of which in this case are prolyl hydroxylases (PHDs) [48]. These enzymes mark hypoxiainducible factor- $1 \alpha$ (HIF1 $\alpha$ for degradation by the UPS. The stability of PHD 1 and PHD 3 is regulated by both Siah-1 and Siah-2 ubiquitin ligases [49]. The result of LMP1-dependent Siah up-regulation in epithelial cells is that HIF $\alpha$ levels are increased and become active HIF $\alpha$ responsive genes $[48,50]$. These are recent observations and physiological reasons for the distinct functional roles of Siah ubiquitin ligases in the different cell types are unknown. 
Another EBV latent membrane protein, 2A (LMP2A), acts as a surrogate $\mathrm{B}$-cell receptor by providing constitutive signaling required for B-cell development and survival [51]. LMP2A signaling appears to be regulated in B-cells by association with members of the HECT domain-containing Nedd 4 family of ubiquitin ligases $[52,53]$ and likely utilizes ubiquitin-mediated degradation through the proteasome complex to regulate the strength of its own signal. Such processes could allow LMP2A to modulate B-cell pathways such as differentiation, activation or survival [51].

A further EBV latent antigen, EBNA 3C, targets the tumor suppressor $\mathrm{pRb}$ for proteasome-dependent degradation through the well known SCFkp2 ubiquitin ligase in different systems including B-cells [54]. Besides directing ubiquitylation that leads to proteasomal degradation, EBV can also affect the regulatory lysine 63 ubiquitylation of IRF7 (the master regulator of type I IFN responses), which leads to its activation instead of degradation [55].

\section{Cervical carcinoma and HPV}

While Kaposi's sarcoma and B-cell lymphoma are the main viral malignancies associated with AIDS, and their connection with HIV infection are hallmarks of the condition, the association between HIV/AIDS and cervical and anal cancer is less obvious [56,57]. However, in 1993 a revised classification system for HIV infection listed invasive cervical cancer as one of the AIDS-defining malignancies [58], and there is growing evidence that HIV infection is associated with increased prevalence and severity of HPV-containing malignant cervical lesions $[9,59,60]$.

More than $95 \%$ of all cervical carcinomas contain at least one copy of one of the HPV genotypes $16 \& 18$ as well as other types that pose a high risk for the malignancy [61]. The HPV E6 and E7 genes are the only viral genes that are retained and expressed in tumor tissue, and their role in HPV-induced carcinogenesis is well established [61-63]. Both proteins cause down-regulation of crucial tumor suppressors; E6 inhibits p53 [64-68] and E7 inactivates the retinoblastoma family proteins (pRb) [69-72]. Both E6 and E7 utilize the UPS to target these proteins for degradation and thus inactivation [73]. These interactions are recognized as classic oncogenic mechanisms; they operate in place of mutation of p53 and pRb.

HPV E6 recruits E6-associated protein (E6-AP), now recognized to be an E3 ligase; this E6-E6-AP complex then binds to p53, resulting in E6-AP-mediated ubiquitylation and proteasomal degradation of p53 $[67,74,75]$. From the perspective of cancer cell biology, this interaction is of interest because the virus product alters endogenous substrate specificity; normally, p53 is a target for Mdm2 ubiq- uitin ligase-mediated ubiquitylation and degradation $[76,77]$.

The mechanism of E7-induced proteasomal degradation of $\mathrm{pRb}$ is still unclear $[73,78]$. One possibility is that E7 recruits a cellular ubiquitin ligase that targets $\mathrm{pRb}$ for ubiquitylation and subsequent degradation. This model is supported by the finding that co-expression of $\mathrm{pRb}$ with the Rb-binding-deficient E7 mutant causes a consistent increase in pRb-induced contact-inhibited cell growth in culture [79]. Another possibility is that E7 could function as an adaptor between $\mathrm{pRb}$ and the proteasome, thereby targeting $\mathrm{pRb}$ directly to the proteasome without prior ubiquitylation, since it has been reported that E7 interacts with the ATPase subunit of the 19S regulatory complex of the $26 \mathrm{~S}$ proteasome [80].

\section{Disease models, knockouts and assays}

Animal models that mimic human cancers caused by viruses are obviously important for understanding the tumor biology of AIDS-associated malignancies, as well as for evaluating the effect of potential anti-tumor and antiviral drugs. Although there is currently still no animal model that accurately represents KSHV, EBV or HPV pathogenesis, mouse models have been established that attempt to address specific factors known to contribute to the development of the diseases. For example, murine gammaherpesvirus $68(\gamma \mathrm{HV}-68)$ is used as a rodent model to help understand the pathogenesis of EBV and KSHV. Several reviews of $\gamma \mathrm{HV}-68$ have documented advances made toward understanding the pathogenesis of AIDSassociated malignancies in the context of these two human viruses [81-83].

Another approach is the transplantation of human tumor tissue to mice with severe combined immunodeficiency disease (SCID), which provides valuable models for viral carcinogenesis and also demonstrates the strict species barrier for infection by human viruses [84-87].

As for the roles of the UPS in virus-related cancers, cultured cell lines are still the primary model used at present to study the relations between viral oncogenes and the components of the UPS.

Crucial proof of the transforming potential of KSHV came from de novo infection of cultured bone marrow (microvascular) endothelial cells and human umbilical vein endothelial cells (HUVECs). KSHV infection conferred long-term survival of both cell types and anchorage-independent growth of HUVECs [88]. Continuous KSHV infection and also conditional, productive viral replication in cells cultured from primary effusion lymphoma (PEL) (a rare B-cell non-Hodgkin's lymphoma) [89] provide additional models. 
The ability of EBV to immortalize normal human B-lymphocytes in vitro and to transform them into lymphoblastoid cell lines (LCLs) generates a cell-culture model of AIDS-associated EBV lymphomas [90]. Virus-containing B-lymphoblastoid cell lines that have been derived from primary tumors are also suitable as in vitro model systems [91].

Numerous cell lines infected with HPV serve as model cell culture systems to study different aspects of tumorigenesis, but perhaps the most relevant system for evaluating the transforming potential of the HPV oncoproteins is immortalization of primary human keratinocytes, which are the natural host cells of this virus in vivo[92]. HPVimmortalized cells are not tumorigenic in nude mice, although they display altered growth and differentiation.

Due to the oncogenic properties of HPV E6 and E7, these proteins have been the focus of most studies on cervical carcinogenesis [64,93-95]. Although the majority of the studies have been performed using cell culture models, several in vivo mouse model systems have been developed for the study of HPV-dependent carcinogenesis [96].

\section{Disease targets and ligands}

Both HPV E6 and E7 dysregulate the UPS so that there is down-regulation of the tumor suppressors p53 and pRb. Since both E6 and E7 are immunogenic, these viral products present potential targets for therapeutic vaccines [97101].

As the UPS is closely involved in the regulation of numerous signaling pathways in tumor cells, it has in the last several years become an attractive target for anti-cancer therapy. The use of proteasome inhibitors to block the final stage in the UPS, proteolysis in the proteasome, presents the opportunity to manipulate intracellular processes in cancer cells for tangible benefit [102-106]. Yet, the functional activity of the UPS is crucial for normal cell function; blockade of protein degradation by proteasome inhibitors causes accumulation of misfolded or damaged proteins, which in turn leads to cell death $[107,108]$. At the same time, there is much evidence that some proteasome inhibitors are more cytotoxic to proliferating malignant cells than to normal quiescent cells [109].

The first of this new proteasome-inhibiting class of drugs to be on the market, bortezomib (Velcade, formerly known as PS-341), shows promising results in clinical trials with different types of cancer specifically by inhibiting the oncogenic NF-kB signaling pathway $[110,111]$. Since

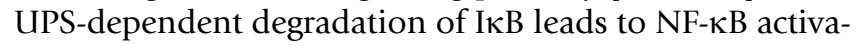
tion (as observed in most known malignancies including those that are AIDS-related [112]), bortezomib could be a candidate for the treatment of the virus-related cancers. In in vitro studies, bortezomib has demonstrated activity against a variety of malignancies by inducing apoptosis in cancer cells and increasing sensitivity of tumor cells to radiation or chemotherapy [113]. Since bortezomib is proving to be highly efficient for treatment of multiple myeloma and also shows promise for lymphoid cancers $[113,114]$, it could be useful in the treatment of EBVinduced B-lymphomas, which are the second most common AIDS-related malignancy.

Since latent infection with these three DNA viruses is the basis for tumorigenesis, induction of the viral lytic cycle, leading to death of virus-infected malignant cells, is a potential antiviral strategy $[115,116]$. Recent study shows that bortezomib induces KSHV lytic gene expression in vitro in two latently KSHV-infected lymphoma cell lines [117]. This result suggests that the UPS regulates viral reactivation and that proteasome inhibitors could have similar effects on other latently infected virus-associated malignant cells.

Also, targeting of other steps of the UPS, such as specific ubiquitin ligases or deubiquitylating enzymes, could produce more selective effects since ubiquitylating and deubiquitylating complexes specifically bind to potential substrates. KSHV ubiquitin ligases K3 and K5 could be good examples of such targets.

\section{Next frontiers}

The effect of bortezomib and other proteasome inhibitors in virus-associated malignancies needs to be defined further. Viral products themselves are closely involved in UPS-dependent regulation and therefore the effects of proteasome inhibitors can be unexpected. For instance, it has been shown on one hand that proteasome inhibitors inhibit HIV budding [118] and on the other hand that inhibition of proteasome function can enhance HIV-1 infection [119].

Generally, present knowledge of how UPS modulators affect AIDS/HIV-associated or other virus-related malignancies is very limited and calls for further investigation. Recent information on the relations between tumor viruses and the host cell system is summarized in Table 1.

Despite the limitations of in vivo model systems for virusrelated human malignancies, some (for example, human peripheral blood lymphocytes (hu-PBL) engrafted in SCID mice) could facilitate screening and preliminary testing of proteasome inhibitors.

Finally, there is no doubt that in the broader panorama of other cancers associated with viruses, such as human Tcell lymphotropic virus-1 (HLTV-1: leukemia), hepatitis B and $\mathrm{C}$ viruses (HBV and HCV: hepatocellular carcinoma), 
Table I: Viral products manipulate the ubiquitin system in AIDS-related cancers. Summarized here is recent information on the relations between tumor viruses and host cell systems. The general strategy through which the ubiquitin system is manipulated, the effector proteins and the host target proteins are indicated for KSHV, EBV and HPV.

\begin{tabular}{llll}
\hline Malignancies & Kaposi's sarcoma (KSHV) & Immunoblastic B-cell lymphomas (EBV) & Cervical cancer (HPV) \\
Strategy & Virus-encoded ubiquitin ligases & Dysregulation of host ubiquitin system & Dysregulation of host ubiquitin system \\
Viral Effectors & KSHV K3, K5 and RTA & EBV LMPI & HPV E6 and E7 \\
Cellular Targets & MHC class I, IRF7 & $\beta$-catenin, PHD/HIFa, IRF7 & p53, pRb \\
\hline
\end{tabular}

as well as EBV (nasopharyngeal and gastric carcinomas, Burkitt's and Hodgkin's lymphomas) and HPV (cervical cancer) in non-immunocompromised patients, many aspects of the UPS are at work and will offer targets for therapy.

\section{Competing interests}

The authors declare that they have no competing interests.

\section{Acknowledgements}

This article has been published as part of BMC Biochemistry Volume 8 Supplement I, 2007: Ubiquitin-Proteasome System in Disease Part I. The full contents of the supplement are available online at http://www.biomedcen tral.com/ $/ 47|-209| / 8$ ? issue=SI.

\section{References}

I. Ambinder R. F.: Viruses as potential targets for therapy in HIVassociated malignancies. Hematol Oncol Clin North Am 2003, 1 7:697-702. v-vi

2. Cheung M. C., Pantanowitz L., Dezube B. J.: AIDS-related malignancies: emerging challenges in the era of highly active antiretroviral therapy. Oncologist 2005, 10:4I2-26.

3. Goedert J. J.: The epidemiology of acquired immunodeficiency syndrome malignancies. Semin Oncol 2000, 27:390-40I.

4. Shah M. H., Porcu P., Mallery S. R., Caligiuri M. A.: AIDS-associated malignancies. Cancer Chemother Biol Response Modif 2003, 21:717-46.

5. Armstrong W., Calabrese L., Taege A. J.: HIV update 2005: origins, issues, prospects, and complications. Cleve Clin J Med 2005, 72:73-8.

6. Gates A. E., Kaplan L. D.: AIDS malignancies in the era of highly active antiretroviral therapy. Oncology (Williston Park) 2002, 16:657-65. discussion 665, 668-70

7. Bellan C., De Falco G., Lazzi S., Leoncini L.: Pathologic aspects of AIDS malignancies. Oncogene 2003, 22:6639-45.

8. Bower M., Palmieri C., Dhillon T.: AIDS-related malignancies: changing epidemiology and the impact of highly active antiretroviral therapy. Curr Opin Infect Dis 2006, 19:14-9.

9. Aoki Y., Tosato G.: Neoplastic conditions in the context of HIV-I infection. Curr HIV Res 2004, 2:343-9.

10. Hille J. J., Webster-Cyriaque J., Palefski J. M., Raab-Traub N.: Mechanisms of expression of HHV8, EBV and HPV in selected HIV associated oral lesions. Oral Dis 2002, 8(Suppl 2): $|6|-8$.

II. Pagano J. S., Blaser M., Buendia M. A., Damania B., Khalili K., RaabTraub N., Roizman B.: Infectious agents and cancer: criteria for a causal relation. Semin Cancer Biol 2004, 14:453-71.

12. Ciechanover A., Orian A., Schwartz A. L.: Ubiquitin-mediated proteolysis: biological regulation via destruction. Bioessays 2000, 22:442-5।.

13. Shackelford J., Pagano J. S.: Tumor viruses and cell signaling pathways: deubiquitination versus ubiquitination. Mol Cell Biol 2004, 24:5089-93.

14. Shackelford J., Pagano JS: Targeting of host-cell ubiquitin pathways by viruses. In The Ubiquitin-Proteasome System Volume 41. Edited by: R. L. J Mayer. Portland Press, London, UK; 2005:I39-156.

15. Bubman D., Cesarman E.: Pathogenesis of Kaposi's sarcoma. Hematol Oncol Clin North Am 2003, 17:717-45.

16. Viejo-Borbolla A., Ottinger M., Schulz T. F.: Human herpesvirus 8: biology and role in the pathogenesis of Kaposi's sarcoma and other AIDS-related malignancies. Curr HIVIAIDS Rep 2004, I:5-II.

17. Viejo-Borbolla A., Schulz T. F.: Kaposi's sarcoma-associated herpesvirus (KSHV/HHV8): key aspects of epidemiology and pathogenesis. AIDS Rev 2003, 5:222-9.

18. Aversa S. M., Cattelan A. M., Salvagno L., Crivellari G., Banna G. Trevenzoli M., Chiarion-Sileni V., Monfardini S.: Treatments of AIDS-related Kaposi's sarcoma. Crit Rev Oncol Hematol 2005, 53:253-65.

19. Dittmer D. P., Vahrson W., Staudt M., Hilscher C., Fakhari F. D.: Kaposi's sarcoma in the era of HAART-an update on mechanisms, diagnostics and treatment. AIDS Rev 2005, 7:56-6I.

20. Stebbing J., Sanitt A., Nelson M., Powles T., Gazzard B., Bower M.: A prognostic index for AIDS-associated Kaposi's sarcoma in the era of highly active antiretroviral therapy. Lancet 2006, 367: 1495-502.

2I. Vanni T., Sprinz E., Machado M. W., Santana R. D., Fonseca B. A. Schwartsmann G.: Systemic treatment of AIDS-related Kaposi sarcoma: Current status and perspectives. Cancer Treat Rev 2006.

22. Reinstein E.: Immunologic aspects of protein degradation by the ubiquitin-proteasome system. Isr Med Assoc / 2004, 6:420-4

23. Rivett A. J., Hearn A. R.: Proteasome function in antigen presentation: immunoproteasome complexes, Peptide production, and interactions with viral proteins. Curr Protein Pept Sci 2004, 5: 153-61.

24. Benichou S., Benmerah A.: The HIV nef and the Kaposi-sarcoma-associated virus K3/K5 proteins: "parasites" of the endocytosis pathway]. Med Sci (Paris) 2003, 19:100-6.

25. Coscoy L., Sanchez D. J., Ganem D.: A novel class of herpesvirusencoded membrane-bound E3 ubiquitin ligases regulates endocytosis of proteins involved in immune recognition. Cell Biol 200I, 155:1265-73.

26. Sanchez D. J., Coscoy L., Ganem D.: Functional organization of MIR2, a novel viral regulator of selective endocytosis. J Biol Chem 2002, 277:6124-30.

27. Coscoy L., Ganem D.: Kaposi's sarcoma-associated herpesvirus encodes two proteins that block cell surface display of MHC class I chains by enhancing their endocytosis. Proc Natl Acad Sci U S A 2000, 97:805I-6.

28. Hewitt E. W., Duncan L., Mufti D., Baker J., Stevenson P. G., Lehner P. J.: Ubiquitylation of MHC class I by the $\mathrm{K} 3$ viral protein signals internalization and TSGIOI-dependent degradation. Embo f 2002, 21:2418-29.

29. Cadwell K., Coscoy L.: Ubiquitination on nonlysine residues by a viral E3 ubiquitin ligase. Science 2005, 309: I 27-30.

30. Duncan L. M., Piper S., Dodd R. B., Saville M. K., Sanderson C. M., Luzio J. P., Lehner P. J.: Lysine-63-linked ubiquitination is required for endolysosomal degradation of class I molecules. Embo J 2006, 25: 1635-45.

31. Yu Y., Wang S. E., Hayward G. S.: The KSHV immediate-early transcription factor RTA encodes ubiquitin E3 ligase activity that targets IRF7 for proteosome-mediated degradation. Immunity 2005, 22:59-70.

32. Herrmann K., Niedobitek G.: Epstein-Barr virus-associated carcinomas: facts and fiction. J Pathol 2003, 199:140-5.

33. Raab-Traub N.: Epstein-Barr virus in the pathogenesis of NPC. Semin Cancer Biol 2002, I 2:43 I-4I.

34. Rickinson A., Kieff E.: Epstein-Barr virus. In Virology 4rd ed. edition. Edited by: P. M. Howley. Lippincott-Raven Publishers, Philadelphia, Pa; 2001 .

35. Tao Q., Young L. S., Woodman C. B., Murray P. G.: Epstein-Barr virus (EBV) and its associated human cancers--genetics, epi- 
genetics, pathobiology and novel therapeutics. Front Biosci 2006, I I:2672-7I3.

36. Young L. S., Murray P. G.: Epstein-Barr virus and oncogenesis: from latent genes to tumours. Oncogene 2003, 22:5I 08-2I.

37. Young L. S., Rickinson A. B.: Epstein-Barr virus: $\mathbf{4 0}$ years on. Nat Rev Cancer 2004, 4:757-68.

38. Gottschalk S., Rooney C. M., Heslop H. E.: Post-transplant lymphoproliferative disorders. Annu Rev Med 2005, 56:29-44.

39. Rui L., Goodnow C. C.: Lymphoma and the control of B cell growth and differentiation. Curr Mol Med 2006, 6:29I-308.

40. Shimoyama Y., Nakamura S., Asano N., Oshiro A., Oyama T.: [Epstein-Barr virus (EBV)-associated lymphomas and lymphoproliferative disorders]. Nippon Rinsho 2006, 64(Suppl 3):635-8

4I. Taylor A. L., Marcus R., Bradley J. A.: Post-transplant lymphoproliferative disorders (PTLD) after solid organ transplantation. Crit Rev Oncol Hematol 2005.

42. Yin C. C., Medeiros L. J., Abruzzo L. V., Jones D., Farhood A. I., Thomazy V. A.: EBV-associated B- and T-cell posttransplant lymphoproliferative disorders following primary EBV infection in a kidney transplant recipient. Am J Clin Pathol 2005, 1 23:222-8.

43. Masucci M. G.: Epstein-Barr virus oncogenesis and the ubiquitin-proteasome system. Oncogene 2004, 23:2107-I5.

44. Dantuma N. P., Masucci M. G.: The ubiquitin/proteasome system in Epstein-Barr virus latency and associated malignancies. Semin Cancer Biol 2003, 13:69-76.

45. Dantuma N. P., Sharipo A., Masucci M. G.: Avoiding proteasomal processing: the case of EBNAI. Curr Top Microbiol Immunol 2002, 269:23-36

46. Jang K. L., Shackelford J., Seo S. Y., Pagano J. S.: Up-regulation of beta-catenin by a viral oncogene correlates with inhibition of the seven in absentia homolog $I$ in B lymphoma cells. Proc Natl Acad Sci U S A 2005, 102: I843I-6.

47. Shackelford J., Maier C., Pagano J. S.: Epstein-Barr virus activates beta-catenin in type III latently infected B lymphocyte lines: association with deubiquitinating enzymes. Proc Natl Acad Sci U S A 2003, 100:15572-6.

48. Kondo S., Seo S. Y., Yoshizaki T., Wakisaka N., Furukawa M., Joab I., Jang K. L., Pagano J. S.: EBV latent membrane protein I up-regulates hypoxia-inducible factor I alpha through Siah I-mediated down-regulation of prolyl hydroxylases $I$ and 3 in nasopharyngeal epithelial cells. Cancer Res 2006, 66:9870-7.

49. Nakayama K., Ronai Z.: Siah: new players in the cellular response to hypoxia. Cell Cycle 2004, 3:1345-7.

50. Wakisaka N., Pagano J. S.: Epstein-Barr virus induces invasion and metastasis factors. Anticancer Res 2003, 23:2133-8.

5I. Portis T., lkeda M, Longnecker R: Epstein-Barr virus LMP2A: regulating cellular ubiquitination processes for maintenance of viral latency? Trends Immunol 2004, 25:422-6.

52. Ikeda M., Ikeda A., Longan L. C., Longnecker R.: The Epstein-Barr virus latent membrane protein $2 A$ PY motif recruits $W W$ domain-containing ubiquitin-protein ligases. Virology 2000, 268: $|78-9|$.

53. Winberg G., Matskova L., Chen F., Plant P., Rotin D., Gish G., Ingham $R$. Ernberg I., Pawson T. Latent membrane protein $2 A$ of Epstein-Barr virus binds WW domain E3 protein-ubiquitin ligases that ubiquitinate B-cell tyrosine kinases. Mol Cell Biol 2000, 20:8526-35.

54. Knight J. S., Sharma N., Robertson E. S.: Epstein-Barr virus latent antigen $3 \mathrm{C}$ can mediate the degradation of the retinoblastoma protein through an SCF cellular ubiquitin ligase. Proc Natl Acad Sci U S A 2005, 102:18562-6.

55. Huye L., Ning S., Pagano J.: Interferon Regulatory Factor $\mathbf{7}$ is Activated by a Viral Oncoprotein through RIP-Dependent Ubiquitination. Mol Cell Biol 2007, 27(8):2910-2918.

56. Goedert J. J., Cote T. R., Virgo P., Scoppa S. M., Kingma D. W., Gail M. H., Jaffe E. S., Biggar R. J.: Spectrum of AIDS-associated malignant disorders. Lancet 1998, 35 I: 1833-9.

57. Rabkin C. S., Biggar R. J., Baptiste M. S., Abe T., Kohler B. A., Nasca $P$. C.: Cancer incidence trends in women at high risk of human immunodeficiency virus (HIV) infection. Int J Cancer 1993, 55:208-12.

58. 1993 revised classification system for HIV infection and expanded surveillance case definition for AIDS among ado- lescents and adults. MMWR Recomm Rep 1992, 4I:I-I9. [No authors listed]

59. Del Mistro A., Chieco Bianchi L.: HPV-related neoplasias in HIVinfected individuals. Eur J Cancer 200I, 37:|227-35.

60. Nicol A. F., Fernandes A. T., Bonecini-Almeida Mda G.: Immune response in cervical dysplasia induced by human papillomavirus: the influence of human immunodeficiency virus-I coinfection -- review. Mem Inst Oswaldo Cruz 2005, 100: I-12.

61. zur Hausen $\mathrm{H}$.: Papillomaviruses causing cancer: evasion from host-cell control in early events in carcinogenesis. J Natl Cancer Inst 2000, 92:690-8.

62. de Villiers E. M., Fauquet C., Broker T. R., Bernard H. U., zur Hausen $\mathrm{H}$.: Classification of papillomaviruses. Virology 2004, 324: 17-27.

63. Palefsky J.: Biology of HPV in HIV infection. Adv Dent Res 2006, 19:99-105.

64. Huibregtse J. M., Beaudenon S. L.: Mechanism of HPV E6 proteins in cellular transformation. Semin Cancer Biol 1996, 7:3 17-26.

65. Mantovani F., Banks L.: The interaction between $\mathrm{p} 53$ and papillomaviruses. Semin Cancer Biol 1999, 9:387-95.

66. Scheffner M., Werness B. A., Huibregtse J. M., Levine A. J., Howley P. M.: The E6 oncoprotein encoded by human papillomavirus types 16 and 18 promotes the degradation of p53. Cell 1990 , 63:1129-36.

67. Thomas M., Pim D., Banks L.: The role of the E6-p53 interaction in the molecular pathogenesis of HPV. Oncogene 1999 , 18:7690-700.

68. Tommasino M., Accardi R., Caldeira S., Dong W., Malanchi I., Smet A., Zehbe I.: The role of TP53 in Cervical carcinogenesis. Hum Mutat 2003, 21:307-12.

69. Dyson N., Howley P. M., Munger K., Harlow E.: The human papilloma virus-16 E7 oncoprotein is able to bind to the retinoblastoma gene product. Science 1989, 243:934-7.

70. Helt A. M., Galloway D. A.: Mechanisms by which DNA tumor virus oncoproteins target the $\mathbf{R b}$ family of pocket proteins. Carcinogenesis 2003, 24:159-69.

7I. Howley P. M., Munger K., Romanczuk H., Scheffner M., Huibregtse I. M.: Cellular targets of the oncoproteins encoded by the cancer associated human papillomaviruses. Princess Takamatsu Symp 1991, 22:239-48.

72. Munger K., Werness B. A., Dyson N., Phelps W. C., Harlow E., Howley P. M.: Complex formation of human papillomavirus E7 proteins with the retinoblastoma tumor suppressor gene product. Embo J 1989, 8:4099-105.

73. Scheffner M., Whitaker N. J.: Human papillomavirus-induced carcinogenesis and the ubiquitin-proteasome system. Semin Cancer Biol 2003, 13:59-67.

74. Talis A. L., Huibregtse J. M., Howley P. M.: The role of E6AP in the regulation of p53 protein levels in human papillomavirus (HPV)-positive and HPV-negative cells. J Biol Chem 1998, 273:6439-45.

75. Thomas M., Banks L.: Inhibition of Bak-induced apoptosis by HPV-18 E6. Oncogene 1998, 17:2943-54.

76. Hengstermann A., Linares L. K., Ciechanover A., Whitaker N. J., Scheffner M.: Complete switch from Mdm2 to human papillomavirus E6-mediated degradation of p53 in cervical cancer cells. Proc Natl Acad Sci U S A 200I, 98:1218-23.

77. Honda R., Tanaka H., Yasuda H.: Oncoprotein MDM2 is a ubiquitin ligase E3 for tumor suppressor p53. FEBS Lett 1997, 420:25-7.

78. Wang J., Sampath A., Raychaudhuri P., Bagchi S.: Both Rb and E7 are regulated by the ubiquitin proteasome pathway in HPVcontaining cervical tumor cells. Oncogene 200I, 20:4740-9.

79. Gonzalez S. L., Stremlau M., He X., Basile J. R., Munger K.: Degradation of the retinoblastoma tumor suppressor by the human papillomavirus type $16 \mathrm{E7}$ oncoprotein is important for functional inactivation and is separable from proteasomal degradation of E7. J Virol 200I, 75:7583-9I.

80. Berezutskaya E., Bagchi S.: The human papillomavirus E7 oncoprotein functionally interacts with the $S 4$ subunit of the $26 \mathrm{~S}$ proteasome. I Biol Chem 1997, 272:30135-40.

8I. Gasper-Smith N., Bost K. L.: Initiation of the host response against murine gammaherpesvirus infection in immunocompetent mice. Viral Immunol 2004, 17:473-80.

82. Mistrikova J., Raslova H., Mrmusova M., Kudelova M.: A murine gammaherpesvirus. Acta Virol 2000, 44:2 I I-26. 
83. Simas J. P., Efstathiou S.: Murine gammaherpesvirus 68: a model for the study of gammaherpesvirus pathogenesis. Trends Microbiol 1998, 6:276-82.

84. Amado R. G., Mitsuyasu R. T., Zack J. A.: Gene therapy for the treatment of AIDS: animal models and human clinical experience. Front Biosci 1999, 4:D468-75.

85. Bonyhadi M. L., Kaneshima H.: The SCID-hu mouse: an in vivo model for HIV-I infection in humans. Mol Med Today 1997, 3:246-53.

86. Mosier D. E.: Modeling AIDS in a mouse. Hosp Pract (Minneap) 1996, 3 I: 4I -8. 53-5, 59-60

87. Trimble J. J., Salkowitz J. R., Kestler H. W.: Animal models for AIDS pathogenesis. Adv Pharmacol 2000, 49:479-5।4.

88. Flore O., Rafii S., Ely S., O'Leary J. J., Hyjek E. M., Cesarman E.: Transformation of primary human endothelial cells by Kaposi's sarcoma-associated herpesvirus. Nature 1998, 394:588-92.

89. Dourmishev L. A., Dourmishev A. L., Palmeri D., Schwartz R. A. Lukac D. M.: Molecular genetics of Kaposi's sarcoma-associated herpesvirus (human herpesvirus-8) epidemiology and pathogenesis. Microbiol Mol Biol Rev 2003, 67:175-2 I2. table of contents

90. Nilsson K.: Human B-lymphoid cell lines. Hum Cell 1992, 5:25-4l.

91. Drexler H. G., MacLeod R. A.: Leukemia-lymphoma cell lines as model systems for hematopoietic research. Ann Med 2003, 35:404-12.

92. Munger K., Howley P. M.: Human papillomavirus immortalization and transformation functions. Virus Res 2002, 89:2/3-28.

93. Finzer P., Aguilar-Lemarroy A., Rosl F.: The role of human papillomavirus oncoproteins E6 and E7 in apoptosis. Cancer Lett 2002, 188:15-24

94. McGlennen R. C.: Human papillomavirus oncogenesis. Clin Lab Med 2000, 20:383-406.

95. Zwerschke W., Jansen-Durr P.: Cell transformation by the E7 oncoprotein of human papillomavirus type 16: interactions with nuclear and cytoplasmic target proteins. Adv Cancer Res 2000, 78: I-29.

96. Eckert R. L., Crish J. F., Balasubramanian S., Rorke E. A.: Transgenic animal models of human papillomavirus-dependent disease (Review). Int J Oncol 2000, 16:853-70.

97. Christensen N. D.: Emerging human papillomavirus vaccines. Expert Opin Emerg Drugs 2005, 10:5-19.

98. Govan V. A.: Strategies for human papillomavirus therapeutic vaccines and other therapies based on the e6 and e7 oncogenes. Ann N Y Acad Sci 2005, 1056:328-43.

99. Kim S. W., Yang J. S.: Human papillomavirus type 16 E5 protein as a therapeutic target. Yonsei Med J 2006, 47:I-14.

100. Mahdavi A., Monk B. J.: Vaccines against human papillomavirus and cervical cancer: promises and challenges. Oncologist 2005, 10:528-38.

I0I. Shillitoe E. J.: Papillomaviruses as targets for cancer gene therapy. Cancer Gene Ther 2006, I 3:445-50.

102. Elliott P. J., Ross J. S.: The proteasome: a new target for novel drug therapies. Am J Clin Pathol 200I, I I 6:637-46.

103. Kisselev A. F., Goldberg A. L.: Proteasome inhibitors: from research tools to drug candidates. Chem Biol 200I, 8:739-58.

104. Monneret C., Buisson J. P., Magdelenat H.: [A new therapy with bortezomib, an oncologic medicinal product of the year 2004]. Ann Pharm Fr 2005, 63:343-9.

105. Rajkumar S. V., Richardson P. G., Hideshima T., Anderson K. C.: Proteasome inhibition as a novel therapeutic target in human cancer. J Clin Oncol 2005, 23:630-9.

106. Tsukamoto S., Yokosawa H.: Natural products inhibiting the ubiquitin-proteasome proteolytic pathway, a target for drug development. Curr Med Chem 2006, 13:745-54.

107. Adams J.: The proteasome: a suitable antineoplastic target. Nat Rev Cancer 2004, 4:349-60.

108. Goldberg A. L., Rock K.: Not just research tools--proteasome inhibitors offer therapeutic promise. Nat Med 2002, 8:338-40.

109. Chauhan D., Hideshima T., Anderson K. C.: Proteasome inhibition in multiple myeloma: therapeutic implication. Annu Rev Pharmacol Toxicol 2005, 45:465-76.

I 10. Richardson P. G., Mitsiades C., Hideshima T., Anderson K. C.: Proteasome inhibition in the treatment of cancer. Cell Cycle 2005 4:290-6.
III. Zavrski I., Jakob C., Schmid P., Krebbel H., Kaiser M., Fleissner C., Rosche M., Possinger K., Sezer O.: Proteasome: an emerging target for cancer therapy. Anticancer Drugs 2005, 16:475-81.

112. Pande V., Ramos M. J.: NF-kappaB in human disease: current inhibitors and prospects for de novo structure based design of inhibitors. Curr Med Chem 2005, I 2:357-74.

I 3. Richardson P. G., Mitsiades C., Hideshima T., Anderson K. C.: Bortezomib: proteasome inhibition as an effective anticancer therapy. Annu Rev Med 2006, 57:33-47.

I I4. Orlowski R. Z., Zeger E. L.: Targeting the proteasome as a therapeutic strategy against haematological malignancies. Expert Opin Investig Drugs 2006, 15: 1 17-30.

II5. Israel B. F., Kenney S. C.: Virally targeted therapies for EBVassociated malignancies. Oncogene 2003, 22:5122-30.

116. Gershburg E., Pagano J. S.: Epstein-Barr virus infections: prospects for treatment. J Antimicrob Chemother 2005, 56:277-81.

117. Brown H. J., McBride W. H., Zack J. A., Sun R.: Prostratin and bortezomib are novel inducers of latent Kaposi's sarcoma-associated herpesvirus. Antivir Ther 2005, 10:745-5I.

I I8. Schubert U., Ott D. E., Chertova E. N., Welker R., Tessmer U., Princiotta M. F., Bennink J. R., Krausslich H. G., Yewdell J. W.: Proteasome inhibition interferes with gag polyprotein processing, release, and maturation of HIV-I and HIV-2. Proc Natl Acad Sci U S A 2000, 97: 13057-62.

119. Wei B. L., Denton P. W., O'Neill E., Luo T., Foster J. L., Garcia J. V.: Inhibition of lysosome and proteasome function enhances human immunodeficiency virus type I infection. J Virol 2005, 79:5705-12.

\section{Publication history}

Republished from Current BioData's Targeted Proteins database (TPdb; http://www.targetedproteinsdb.com).

Publish with Biomed Central and every scientist can read your work free of charge

"BioMed Central will be the most significant development for disseminating the results of biomedical research in our lifetime. "

Sir Paul Nurse, Cancer Research UK

Your research papers will be:

- available free of charge to the entire biomedical community

- peer reviewed and published immediately upon acceptance

- cited in PubMed and archived on PubMed Central

- yours - you keep the copyright 